\title{
Peningkatan Pertumbuhan dan Hasil Padi Sawah Organik dengan Berbagai Macam Aplikasi Pupuk Hijau Glirisidia
}

\author{
Marti Winarni \\ Fakultas Pertanian, Universitas Merdeka, Jl. Serayu No.79, Kota Madiun, 63133 \\ E-mail: martiwinarni@unmer-madiun.ac.id
}

\begin{abstract}
The object of the study was to obtain the types of application of Glirisidia green manures on the growth and yield of organic rice lowland. The experimental pot experiment was carried out in a randomized block design consisting of one factor and three replications. The treatment factor was 10 various application of Glirisidia leaves. The treatments are: $100 \%$ fresh Glirisidia leaves $+0 \%$ compost; $60 \%$ fresh Glirisidia leaves $+40 \%$ compost; $40 \%$ fresh Glirisidia leaves $+60 \%$ compost; $100 \%$ wind-dried Glirisidia leaves + $0 \%$ compost; $60 \%$ of wind-dried Glirisidia leaves $+40 \%$ compost; $40 \%$ wind-dried Glirisidia leaves $+60 \%$ compost; $100 \%$ sun-dried Glirisidia leaves $+0 \%$ compost; $60 \%$ of the sun-dried Glirisidia leaves $+40 \%$ of compost; $40 \%$ of the sundried Glirisidia leaves $+60 \%$ compost; and $0 \%$ Glirisidia leaves $+100 \%$ compost. The results showed that the various application of Glirisidia leaves increased the grain yield 34, $09 \%$ compared to the application of $0 \%$ Glirisidia leaf $+100 \%$ compost. The grain/ hil of yield could be improved by application of $100 \%$ fresh Glirisidia leaves $+0 \%$ compost $(164,47 \mathrm{~g}$ grain/hill), $100 \%$ of wind-dried Gliricidia leaves $(165,55 \mathrm{~g}$ grain/ hill $)+0 \%$ compost, or $100 \%$ sun-dried Gliricidia leaves + 0\% compost $(169,14 \mathrm{~g}$ grain/ hill)
\end{abstract}

Keywords - : organic rice lowland; green manure; various application of Glirisidia leaves.

\section{PENDAHULUAN}

Penggunaan bahan kimia anorganik menyebabkan degradasi kesuburan tanah dan mengakibatkan pencemaran lingkungan tanah dan air. Pemberian pupuk anorganik secara terus-menerus dan berlebihan setiap musim tanam menurunkan produktivitas tanah dalam jangka waktu tertentu dan akhirnya menurunkan produktivitas tanah untuk waktu yang akan datang (Ikemura \& Shukla, 2009; Hasanuzzaman et al., 2010; Sanati et al., 2011).

Pertanian organik merupakan pertanian alternatif yang aman bagi lingkungan, munculnya disebabkan karena ancaman kerusakan ekologis oleh pencemaran bahan anorganik (Jahroh, 2010). Pertanian organik bergantung pada kesehatan tanah dan daur hara melalui tanah menggunakan proses alami (Ram \& Sharma, 2011), mengandalkan sumber kebutuhan hara melalui pupuk organik dan masukan-masukan alami lainnya (Suriadikarta \& Simanungkalit, 2006). Pada umumnya, petani menggunakan pupuk kandang sapi sebagai sumber nutrisi, terutama $\mathrm{N}$, namun keberadaan pupuk kandang sapi sangat terbatas. Pupuk hijau legum tahunan merupakan salah satu pupuk organik yang berpotensi sebagai sumber bahan organik tanah dan unsur hara tanaman padi sawah terutama N. Salah jenis pupuk hijau legum tahunan adalah dari jenis tanaman Glirisidia, yang memiliki kadar $\mathrm{N}$ tinggi dan dekomposisnya cukup cepat (Winarni, 2016). Pupuk hijau pada umumnya diaplikasikan dalam bentuk segar, namun terdapat masalah pengumpulannya yang memerlukan waktu yang cukup lama. Pupuk hijau dalam bentuk kering angin yang tersimpan untuk beberapa hari (kering angin) atau dalam bentuk kering matahari menjadi alternatif aplikasinya karena bahan pupuk hijau dapat dipersiapkan lebih awal sebelum penanaman tanaman padi.

Aplikasi pupuk hijau dalam berbagai bentuk secara terpadu bersamaan dengan kompos pupuk kandang sapi dalam komposisi yang tepat belum banyak dilaporkan. Oleh karena itu perlu dilakukan penelitian tentang berbagai aplikasi pupuk hijau dengan pupuk kandang yang tepat untuk medapatkan hasil gabah yang maksimal. Tujuan penelitian adalah untuk mendapatkan bentuk aplikasi pupuk hijau Glirisidia yang tepat terhadap pertumbuhan dan hasil padi sawah organik.

Penelitian terdahulu dilakukan Alagappan \& Venkitaswamy (2015) mempelajari aspek berbagai sumber pupuk organik dibandingkan dengan praktek pengelolaan hara terpadu (integrated nutrient management, INM) RDF + Dhaincha (Sesbania cannabina) dan pupuk dosis rekomendasi (recommended dose of fertilizer, RDF) terhadap pertumbuhan dan hasil padi (Oryza sativa L.) untuk menentukan nilai optimal SPAD tahap pertumbuhan tanaman tertentu untuk hasil gabah lebih tinggi. Hasil penelitian menunjukkan bahwa nilai rerata SPAD diperoleh untuk meningkatkan hasil gabah padi optimal untuk pupuk dosis rekomendasi $\operatorname{RDF}(31,6 ; 32,8 ; 34,6$ dan 32,$8 ; 34,6$; 34.8), untuk praktek praktek pengelolaan hara terpadu RDF + Dhaincha $(34,8 ; 35,6 ; 36,4$ dan 35,$0 ; 35,9 ; 36,8)$, untuk $100 \%$ RDN melalui pupuk hijau $(31,4 ; 32,6 ; 34,0$ dan 32,4 ; 34,2; 34,4) dan untuk $100 \%$ RDN melalui masing-masing pupuk kandang tercatat $(31,0 ; 31,8 ; 33,5$ dan 31,$2 ; 33,4$; $34,1)$ pada anakan aktif, inisiasi malai dan fase berbunga padi selama percobaan. Di antara perlakuan pupuk organik, 100\% RDN melalui pupuk hijau Dhaincha memberikan nilai SPAD dan hasil gabah padi tertinggi.

Penelitian yang dilakukan Manjappa (2014) mempelajari aspek pengaruh Eupatorium (Chromolaena odorata) sebagai pupuk daun hijau dengan kombinasi taraf pupuk anorganik pada produktifitas padi. Hasil gabah dan jerami nyata dipengaruhi oleh aplikasi berbagai taraf Eupatorium selama kedua tahun dan data rerata. Hasil gabah padi dengan aplikasi Eupatorium pada 10 t/ha (masing-masing 6569, 6900 dan $6735 \mathrm{~kg} / \mathrm{ha}), 15 \mathrm{t} / \mathrm{ha}(6651,7180$ dan $6691 \mathrm{~kg} / \mathrm{ha})$ dan $20 \mathrm{t} / \mathrm{ha}(6487,7370$ dan $6929 \mathrm{~kg} / \mathrm{ha})$ ditemukan setara satu sama lain selama tahun 2002, 2003 dan reratanya. Hasil 
Website : http://agritek.unmermadiun.ac.id/index.php/agritek

jerami maksimum diperoleh dengan Eupatorium 20 t/ha. Namun, hasil jerami yang peroleh pada taraf Eupatorium 20 $\mathrm{t} / \mathrm{ha}$ ditemukan setara dengan Eupatorium pada taraf $10 \mathrm{t} / \mathrm{ha}$ $(6132 \mathrm{~kg} / \mathrm{ha})$ selama tahun 2002 serta dengan $10 \mathrm{t} / \mathrm{ha}(6280$ $\mathrm{kg} / \mathrm{ha})$ dan $15 \mathrm{t} / \mathrm{ha}(6130 \mathrm{~kg} / \mathrm{ha})$ selama tahun 2003.

Hasil penelitian Tomar et al. (2013) selama musim hujan tiga tahun berturut-turut (2008-2010) untuk mempelajari aspek pengaruh jenis pupuk daun hijau terhadap bahan kering dan produktivitas padi sawah (Oryza sativa L.). Hasil penelitian menunjukkan bahwa selama tahun 2008-2009, komponen hasil dan hasil padi lebih tinggi dalam plot NPK dibandingkan dengan pupuk hijau daun. Namun, pada tahun ketiga, pupuk daun hijau (kecuali Alnus) lebih tinggi dibandingkan perlakuan N-P2O5-K2O rekomendasi dalam hal produksi bahan kering dan hasil, namun respons yang lebih baik pada perlakuan Erythrina. Setelah panen akhir, Ntersedia tanah meningkat $14-20 \%$ pada plot yang diberi perlakuan Alnus dan Erythrina dibandingkan dengan kontrol.

Neelima (2008) mempelajari aspek pengaruh pupuk $\mathrm{N}$ dan pembenaman yang berbeda dari pupuk hijau Sunnhemp terhadap penampilan padi dan neraca hara dalam tanah. Total biomasa yang dihasilkan Sunnhemp adalah $35 \mathrm{t} / \mathrm{ha}$ (29,3 t/ha dari bagian tajuk dan akar 6,7 t/ha). Hasil penelitian menunjukkan bahwa bobot kering maksimal tanaman padi ditemukan karena pembenaman total tanaman $\left(1306 \mathrm{~g} / \mathrm{m}^{2}\right)$ dan tajuk $\left(1264 \mathrm{~g} / \mathrm{m}^{2}\right)$ Sunnhemp dan aplikasi $180 \mathrm{~kg} \mathrm{~N} / \mathrm{ha}\left(1233 \mathrm{~g} / \mathrm{m}^{2}\right)$. Hasil gabah padi nyata lebih tinggi dengan pembenaman total Sunnhemp atau tajuk Sunnhemp. Keseimbangan $\mathrm{N}$ tanah diperoleh dengan pembenaman tanaman total atau tajuk Sunnhemp dan $180 \mathrm{~kg}$ N/ha.

Kebaruan penelitian ini terletak pada eksplorasi sumber pupuk hijau dari daun Glirisidia yang diaplikasikan dalam bentuk segar, kering angin atau kering matahari. Penelitian ini dimaksudkan untuk mempelajari pengaruh macam aplikasi daun Glirisidia dan kompos terhadap pertumbuhan dan hasil padi sawah organik, serta untuk mendapatkan bentuk aplikasi pupuk hijau Glirisidia yang tepat terhadap pertumbuhan dan hasil padi sawah organik.

Pupuk hijau terurai dengan cepat bila dibenamkan dalam tanah dan dapat mengganti pupuk $\mathrm{N}$, terutama dalam masa pertumbuhan vegetatif tanaman. Pemberian pupuk hijau pada lahan sawah akan meningkatkan kadar N, Corganik, KTK dan aktivitas mikroorganisma tanah. Peningkatan kandungan nitrogen dalam tanah akan meningkatkan kadar $\mathrm{N}$ total dan $\mathrm{N}$ tersedia yang berupa $\mathrm{NH}_{4}{ }^{+}$dan $\mathrm{NO}_{3}{ }_{3}^{-}$. Dengan meningkatnya ketersediaan nitrogen dalam tanah dapat meningkatkan serapan nitrogen tanaman termasuk daun. $\mathrm{N}$-anorganik dalam tanaman segera diubah menjadi asam-asam amino dan akhirnya dirangkai menjadi protein tanaman. Peningkatan serapan nitrogen akan meningkatkan pertumbuhan vegetatif tanaman, termasuk daun yang merupakan organ fotosintesis. Meningkatnya luas daun dapat meningkatkan aktivitas proses fotosintesis yang akan memberikan kontribusi positif terhadap komponen hasil. Peningkatan komponen hasil akan meningkatkan hasil gabah.

Nitrogen adalah suatu unsur nutrisi merupakan komponen asam amino, protein, asam nukleat, klorofil, enzim, hormon dan beberapa metabolit esensial lain (Reddy et al., 2006;
Wijaya, 2010; Lakitan, 2012; Sugito, 2012). Nitrat dan amonium adalah sumber utama dari nitrogen anorganik yang diserap oleh akar tanaman tingkat tinggi (Hardjowigeno \& Rayes. 2005).

\section{BAHAN DAN METODE}

Penelitian ini merupakan penelitian eksperimental yang dilakukan di dalam pot (ember plastik) pada kondisi lingkungan lahan sawah. Percobaan dilaksanakan di Desa Sukosari, kecamatan Dagangan, Kabupaten Madiun mulai bulan Pebruari sampai dengan Juli 2018. Analisis tanaman dilaksanakan di Laboratorium Fakultas Pertanian Universitas Merdeka Madiun dan di laboratorium Manajemen Produksi Fakultas Pertanian Universitas Gadjah Mada.

Bahan-bahan yang digunakan dalam percobaan antara lain: daun Glirisidia segar, daun Glirisidia kering angin yang dihamparkan di dalam ruangan (selanjutnya disebut Glirisidia kering angin), daun Glirisidia kering daun kering yang dijemur di bawah sinar matahari (selanjutnya disebut dengan Glirisidia kering matahari), kompos pupuk kandang sapi, benih padi sawah varietas Ciherang. Sebelum diaplikasikan, daun Glirisidia dianalisis terlebih dahulu. Berdasarkan hasil analisis laboratorium yang dilakukan di Laboratorium Tanah di Universitas Gadjah Mada, kandungan kadar $\mathrm{N}$ daun Glirisidia segar adalah $\mathrm{N}$ 4,14\%, daun Glirisidia kering angin 3,13\% dan daun Glirisidia kering matahari 3,34\%. Kompos pupuk kandang sapi memiliki kadar N 1,49\% (Winarni, 2016). Alat-alat utama yang digunakan dalam percobaan ini antara lain: ember plastik, penggaris, oven, timbangan digital, dan area meter.

Percobaan menggunakan Rancangan Acak Kelompok (RAK), terdiri dari satu faktor dan tiga ulangan. Faktor perlakuan adalah daun Glirisidia sebanyak 10 macam. Perlakuan tersebut adalah sebagai berikut: Daun Glirisidia Segar 100\%; daun Glirisidia Segar 60\% + kompos $40 \%$, daun Glirisidia Segar 40\%+ kompos 60\%); daun Glirisidia Simpan 100\% + kompos 0\%; daun Glirisidia kering angin $60 \%$ + kompos $40 \%$; daun Glirisidia kering angin $40 \%+$ kompos 60\%; daun Glirisidia kering matahari $100 \%+$ kompos $0 \%$; daun Glirisidia kering matahari $60 \%+$ kompos $40 \%$ ); daun Glirisidia kering matahari $40 \%+$ kompos $60 \%$ ); dan daun Glirisidia 0\% + kompos $100 \%$.

Persiapan tanah dilakukan dengan cara tanah dikeringanginkan, ditumbuk dan disaring dengan ayakan dengan diameter $2 \mathrm{~mm}$. Tanah sebanyak $40 \mathrm{~kg}$ dimasukkan ke dalam ember plastik dengan ukuran lebar $60 \mathrm{~cm}$ dan tinggi $40 \mathrm{~cm}$, kemudian digenangi. Pupuk hijau daun Glirisidia dan kompos dibenamkan dalam tanah yang telah dimasukkan dalam pot dengan kedalaman $10 \mathrm{~cm}$ sesuai perlakuan. Setelah pupuk hijau diaplikasikan ke dalam pot dan digenangi selama 2 minggu, bibit padi yang telah berumur 3 minggu setelah sebar dipindahtanamkan sebanyak 3 bibit per lubang dan empat rumpun setiap ember. Penyulaman bibit padi dilakukan pada saat tanaman padi berumur 1 minggu setelah tanam (mst). Pupuk hijau dengan takaran $25 \mathrm{t} / \mathrm{ha}$ (500 g/ ember) diaplikasikan dengan cara dibenam 2 (dua) minggu sebelum tanam bibit padi sebagai pupuk dasar (1 minggu setelah persiapan tanah). Pupuk hijau diberikan sebagai pupuk dasar dengan cara dibenamkan secara merata dalam tanah dengan kedalaman $10 \mathrm{~cm}$. Pemupukan 
Website : http://agritek.unmermadiun.ac.id/index.php/agritek

diberikan sebagai pupuk dasar dan diaplikasikan sesuai perlakuan, yaitu: daun Glirisidia Segar 100\%; daun Glirisidia Segar 60\% + kompos 40\%, daun Glirisidia Segar 40\%+ kompos 60\%); daun Glirisidia kering angin 100\% + kompos $0 \%$; daun Glirisidia kering angin $60 \%+$ kompos 40\%; daun Glirisidia kering angin 40\% + kompos 60\%; daun Glirisidia kering matahari $100 \%+$ kompos $0 \%$; daun Glirisidia kering matahari $60 \%+$ kompos $40 \%$ ); daun Glirisidia kering matahari $40 \%$ + kompos $60 \%$ ); dan $0 \%$ daun Glirisidia + kompos 100\%. Pupuk hijau dibenamkan ke dalam tanah 2 minggu sebelum tanam, sedangkan kompos dibenamkan bersamaan waktu tanam. Pengumpulan data dilakukan secara distruktif, meliputi pertumbuhan tanaman dan hasil panen. Pertumbuhan tanaman diamati secara distruktif dengan 2 rumpun sampel pada fase pertumbuhan vegetatif cepat (5 minggu setelah tanam, mst), fase pertumbuhan tanaman maksimal $(10 \mathrm{mst})$ dan pada saat panen (15 mst). Pengamatan pertumbuhan tanaman meliputi variabel-variabel tinggi tanaman $(\mathrm{cm})$, luas daun per rumpun $\left(\mathrm{cm}^{2}\right)$, jumlah anakan maksimal per rumpun, dan bobot kering tanaman per rumpun $(\mathrm{g})$.

Komponen hasil dan hasil panen diamati pada saat panen terhadap variabel-variabel jumlah malai/rumpun, jumlah gabah per malai, bobot 1000 butir gabah, hasil Panen Gabah/Rumpun (g). Analisis data dilakukan dengan menggunakan Analisis Ragam (Analisis of Variance) pada taraf nyata 5 persen. Selanjutnya jika terdapat beda nyata antar perlakuan akan dilanjutkan dengan Uji Berjarak Duncan (Duncan Multiple Range Test $=$ DMRT) pada taraf nyata $5 \%$. Seluruh data dianalisis menggunakan program SAS versi 9.1.3.

\section{HASIL DAN PEMBAHASAN}

\section{A. Pertumbuhan Tanaman Padi}

Penggunaan pupuk hijau daun Glirisidia menyebabkan peningkatan pertumbuhan tanaman padi, yang ditunjukkan pada variabel tinggi tanaman, luas daun/rumpun, jumlah anakan/ rumpun, dan bobot kering tanaman/rumpun. Rerata tinggi tanaman, luas daun/rumpun, jumlah anakan/rumpun, bobot kering tanaman/rumpun pada perlakuan berbagai macam aplikasi pupuk hijau daun Glirisidia disajikan pada Tabel 1.

Tabel 1 menunjukkan bahwa aplikasi daun Glirisidia $100 \%$ dalam bentuk segar tanpa kompos, daun Glirisidia $100 \%$ dalam bentuk kering angin tanpa kompos dan daun Glirisidia $100 \%$ dalam bentuk kering matahari tanpa kompos menyebabkan peningkatan tinggi tanaman, luas daun/ rumpun, jumlah anakan/ rumpun, dan bobot kering tanaman yang tidak berbeda, tetapi lebih tinggi dibandingkan dengan aplikasi daun Glirisidia $60 \%$ segar $+40 \%$ kompos, daun Glirisidia $60 \%$ kering angin $+40 \%$ kompos, daun Glirisidia $60 \%$ kering matahari $+40 \%$ kompos, daun Glirisidia segar $40 \%$ + kompos $60 \%$, daun Glirisidia kering angin $40 \%+$ kompos 60\%, daun Glirisidia kering matahari $40 \%+$ kompos $60 \%$ dan perlakuan $0 \%$ daun Glirisidia $+100 \%$ kompos (tanpa daun Glirisidia dan hanya menggunakan $100 \%$ kompos). Hal ini disebabkan karena tingginya kadar N pupuk yang terkandung dalam daun Glirisidia, masingmasing dalam bentuk segar 4,14\%, kering angin 3,13 dan kering angin $3,145 \%$. Makin tinggi prosentase daun Glirisidia yang digunakan dengan takaran yang tinggi (100\%)

Tabel 1.

Rerata Tinggi Tanaman, Luas Daun/ Rumpun, Jumlah Anakan/ Rumpun, Bobot Kering Tanaman pada Perlakuan Berbagai Macam Aplikasi Pupuk Hijau Glirisidia

\begin{tabular}{|c|c|c|c|c|}
\hline Macam Aplikasi Daun Glirisidia & $\begin{array}{c}\text { Tinggi } \\
\text { Tanaman }(\mathrm{cm})\end{array}$ & $\begin{array}{c}\text { Luas Daun/ } \\
\text { Rumpun }\left(\mathrm{cm}^{2}\right)\end{array}$ & $\begin{array}{l}\text { Jumlah Anakan/ } \\
\text { Rumpun }\end{array}$ & $\begin{array}{l}\text { Bobot Kering } \\
\text { Tanaman }(\mathrm{g})\end{array}$ \\
\hline Glirisidia Segar 100\% + Kompos 0\% & 88,08 a & $1107,76 \mathrm{a}$ & $47,67 \mathrm{a}$ & $81,33 \mathrm{a}$ \\
\hline Glirisidia Segar $60 \%+$ Kompos $40 \%$ & $77,75 \mathrm{~b}$ & $827,56 \mathrm{~b}$ & $37,33 \mathrm{~b}$ & $66,00 \mathrm{~b}$ \\
\hline Glirisidia Segar $40 \%+$ Kompos $60 \%$ & $73,75 \mathrm{~b}$ & $783,83 \mathrm{~b}$ & $30,67 \mathrm{c}$ & $53,00 \mathrm{c}$ \\
\hline Glirisidia kering angin $100 \%+$ Kompos $0 \%$ & 88,67 a & $1112,12 \mathrm{a}$ & $48,00 \mathrm{a}$ & 81,67 a \\
\hline Glirisidia kering angin $60 \%+$ Kompos $40 \%$ & $78,67 \mathrm{~b}$ & $894,20 \mathrm{~b}$ & $38,00 \mathrm{~b}$ & $68,67 \mathrm{~b}$ \\
\hline Glirisidia kering angin $40 \%+$ Kompos $60 \%$ & $76,17 \mathrm{~b}$ & $836,49 \mathrm{~b}$ & $30,33 \mathrm{c}$ & $55,33 \mathrm{c}$ \\
\hline Glirisidia kering matahari $100 \%+$ Kompos $0 \%$ & 89,25 a & $1113,16 \mathrm{a}$ & $50,33 \mathrm{a}$ & $85,33 \mathrm{a}$ \\
\hline Glirisidia kering matahari $60 \%+$ Kompos $40 \%$ & $78,92 \mathrm{~b}$ & $894,20 \mathrm{~b}$ & $41,00 \mathrm{~b}$ & $71,33 \mathrm{~b}$ \\
\hline Glirisidia kering matahari $40 \%+$ Kompos $60 \%$ & $76,17 \mathrm{~b}$ & $813,30 \mathrm{~b}$ & $31,33 \mathrm{c}$ & $57,33 \mathrm{c}$ \\
\hline Glirisidia $0 \%+$ Kompos $100 \%$ & $66,75 \mathrm{c}$ & $650,13 \mathrm{c}$ & $32,00 \mathrm{~d}$ & $44,33 \mathrm{~d}$ \\
\hline Rerata & 79,42 & 896,66 & 38,27 & 66,43 \\
\hline $\mathrm{CV}(\%)$ & 4,77 & 8,57 & 5,80 & 4,48 \\
\hline
\end{tabular}

Keterangan: Angka-angka yang didampingi huruf sama pada kolom yang sama tidak beda nyata pada uji Duncan 5\%

makin banyak $\mathrm{N}$ yang tersedia bagi pertumbuhan tanaman padi. Berbeda dengan kompos pupuk kandang yang mempunyai kandungan $\mathrm{N}$ yang lebih rendah, yaitu 1,49\%.

Perlakuan daun Glirisidia $60 \%$ yang diaplikasikan dalam bentuk segar $+40 \%$ kompos, daun Glirisidia $60 \%$ yang diaplikasikan dalam kering angin $+40 \%$ kompos, daun Glirisidia $60 \%$ yang diaplikasikan dalam kering matahari + $40 \%$ kompos tidak memberikan perbedaan rerata tinggi tanaman dan luas daun/ rumpun dibandingkan dengan perlakuan daun Glirisidia $40 \%$ yang diaplikasikan dalam bentuk segar $+60 \%$ kompos, daun Glirisidia $40 \%$ yang diaplikasikan dalam bentuk kering angin $+60 \%$ kompos dan daun Glirisidia $40 \%$ yang diaplikasikan dalam kering matahari $+60 \%$ kompos. Namun perlakuan tersebut memberikan rerata jumlah anakan/ rumpun dan bobot kering tanaman lebih tinggi dibandingkan dengan perlakuan daun 
Website : http://agritek.unmermadiun.ac.id/index.php/agritek

Glirisidia $40 \%$ yang diaplikasikan dalam bentuk segar + $60 \%$ kompos, daun Glirisidia $40 \%$ yang diaplikasikan dalam bentuk kering angin $+60 \%$ kompos dan daun Glirisidia $40 \%$ yang diaplikasikan dalam kering matahari $+60 \%$ kompos. Rerata tinggi tanaman, luas daun/ rumpun, jumlah anakan/ rumpun dan bobot kering tanaman padi terendah diperoleh pada perlakuan tanpa daun Glirisidia (daun Glirisidia 0\% + $100 \%$ kompos).

Penggunaan daun Glirisidia pada takaran yang sama, masing-masing $100 \%$, 60\% atau $40 \%$ yang diaplikasikan dalam bentuk segar (Kadar N 4,14\%), kering angin (kadar N $3,13 \%)$ dan kering matahari $(3,34)$ tidak menyebabkan perbedaan tinggi tanaman, luas daun per rumpun, jumlah anakan, dan bobot kering tanaman. Hal ini menunjukkan bahwa pengumpulan daun Glirisidia yang dikering anginkan di dalam ruangan maupun dijemur dibawah sinar matahari tidak menurunkan kualitas pupuk daun, sehingga tidak menurunkan pertumbuhan tanaman padi. Hal ini disebabkan karena kadar nitrogen yang terkandung dalam daun Glirisidia hanya menurun sedikit akibat penyimpanan maupun pengeringan dibawah sinar matahari.

\section{B. Komponen Hasil dan Hasil Panen}

Komponen hasil dan hasil panen padi dapat ditingkatkan melalui penggunaan pupuk hijau daun Glirisidia, yang ditunjukkan pada variabel jumlah malai/ rumpun, panjang malai, bobot 1000 biji, bobot gabah/ rumpun, jumlah biji/ malai dan hasil panen gabah/rumpun.

Rerata jumlah malai/rumpun, panjang malai, bobot 1000 biji, jumlah biji/malai padi pada perlakuan berbagai macam aplikasi pupuk hijau Glirisidia disajikan dalam Tabel 2.

Tabel 2 menunjukkan bahwa aplikasi daun Glirisidia $100 \%$ dalam bentuk segar tanpa kompos, daun Glirisidia $100 \%$ dalam bentuk kering angin tanpa kompos dan daun Glirisidia 100\% dalam bentuk kering matahari tanpa kompos

Tabel 2

Rerata Jumlah Malai/ Rumpun, Panjang Malai, Bobot 1000 biji, Jumlah Biji/Malai Padi pada Perlakuan Berbagai Macam Aplikasi Pupuk Hijau Glirisidia

\begin{tabular}{|c|c|c|c|c|}
\hline Macam Aplikasi Daun Glirisidia & $\begin{array}{c}\text { Jumlah Malai/ } \\
\text { Rumpun }\end{array}$ & $\begin{array}{c}\text { Panjang Malai } \\
\left(\mathrm{cm}^{2}\right)\end{array}$ & $\begin{array}{c}\text { Bobot } \\
1000 \text { biji }(\mathrm{g})\end{array}$ & $\begin{array}{c}\text { Jumlah } \\
\text { Biji/Malai }\end{array}$ \\
\hline Glirisidia Segar 100\% + Kompos 0\% & $45,00 \mathrm{a}$ & $23,00 \mathrm{a}$ & $28,80 \mathrm{a}$ & $146,33 \mathrm{a}$ \\
\hline Glirisidia Segar $60 \%+$ Kompos $40 \%$ & $36,67 \mathrm{~b}$ & $20,67 \mathrm{~b}$ & $28,40 \mathrm{a}$ & $128,33 \mathrm{~b}$ \\
\hline Glirisidia Segar $40 \%+$ Kompos $60 \%$ & $27,67 \mathrm{c}$ & $20,00 \mathrm{~b}$ & $27,07 \mathrm{~b}$ & $108,00 \mathrm{c}$ \\
\hline Glirisidia kering angin $100 \%+$ Kompos $0 \%$ & $46,33 \mathrm{a}$ & $23,00 \mathrm{a}$ & $29,20 \mathrm{a}$ & $148,33 \mathrm{a}$ \\
\hline Glirisidia kering angin $60 \%+$ Kompos $40 \%$ & $37,67 \mathrm{~b}$ & $21,00 \mathrm{~b}$ & $28,50 \mathrm{a}$ & $131,00 \mathrm{~b}$ \\
\hline Glirisidia kering angin $40 \%+$ Kompos $60 \%$ & $30,67 \mathrm{c}$ & $20,67 \mathrm{~b}$ & $27,13 \mathrm{~b}$ & $108,67 \mathrm{c}$ \\
\hline Glirisidia kering matahari $100 \%+$ Kompos $0 \%$ & $48,00 \mathrm{a}$ & 23,33 a & $29,37 \mathrm{a}$ & $152,00 \mathrm{a}$ \\
\hline Glirisidia kering matahari $60 \%+$ Kompos $40 \%$ & $39,67 \mathrm{~b}$ & $21,00 \mathrm{~b}$ & $28,60 \mathrm{a}$ & $132,00 \mathrm{~b}$ \\
\hline Glirisidia kering matahari $40 \%+$ Kompos $60 \%$ & $29,33 \mathrm{c}$ & $20,33 \mathrm{~b}$ & $27,27 \mathrm{~b}$ & $118,00 \mathrm{c}$ \\
\hline Glirisidia 0\% + Kompos $100 \%$ & $24,00 \mathrm{~d}$ & $18,33 \mathrm{c}$ & $24,76 \mathrm{c}$ & $95,00 \mathrm{~d}$ \\
\hline Rerata & 36,50 & 21,13 & 27,91 & 126,73 \\
\hline $\mathrm{CV}(\%)$ & 5,06 & 3,94 & 2,02 & 4,27 \\
\hline
\end{tabular}

Keterangan: Angka-angka yang didampingi huruf sama pada kolom yang sama tidak beda nyata pada uji Duncan 5\% menyebabkan peningkatan rerata jumlah malai/rumpun, panjang malai dan jumlah biji/malai yang berbeda nyata dibandingkan dengan aplikasi daun Glirisidia $60 \%$ segar + $40 \%$ kompos, daun Glirisidia 60\% kering angin $+40 \%$ kompos, daun Glirisidia 60\% kering matahari $+40 \%$ kompos, daun Glirisidia segar $40 \%$ + kompos $60 \%$, daun Glirisidia kering angin $40 \%+$ kompos $60 \%$, daun Glirisidia kering matahari $40 \%+$ kompos $60 \%$ dan perlakuan tanpa daun Glirisidia (hanya menggunakan 100\% kompos). Hal ini disebabkan karena tingginya kadar $\mathrm{N}$ pupuk yang terkandung dalam daun Glirisidia. Makin tinggi prosentase daun Glirisidia yang digunakan dengan takaran yang tinggi (100\%) makin banyak $\mathrm{N}$ yang tersedia bagi pertumbuhan tanaman padi. Makin tingginya kandungan $\mathrm{N}$ yang tersedia makin meningkatkan pertumbuhan tanaman padi, dan menyebabkan makin meningkatnya komponen hasil panen dan hasil panen gabah. Sedangkan kompos pupuk kandang sapi mempunyai kandungan $\mathrm{N}$ yang lebih rendah $(1,49 \%)$.

Aplikasi daun Glirisidia $100 \%$ dalam bentuk segar tanpa kompos, daun Glirisidia 100\% dalam bentuk kering angin tanpa kompos dan maupun daun Glirisidia 100\% dalam bentuk kering matahari tanpa kompos menyebabkan peningkatan rerata hasil panen gabah kering giling yang tidak berbeda nyata, namun memberikan hasil lebih tinggi dibandingkan dengan aplikasi daun Glirisidia $60 \%$ segar + $40 \%$ kompos, daun Glirisidia $60 \%$ kering angin $+40 \%$ kompos, daun Glirisidia 60\% kering matahari $+40 \%$ kompos, daun Glirisidia segar $40 \%+$ kompos $60 \%$, daun Glirisidia kering angin $40 \%+$ kompos $60 \%$, daun Glirisidia kering matahari $40 \%+$ kompos $60 \%$ dan perlakuan $0 \%$ daun Glirisidia $+100 \%$ kompos (Gambar 1). Hal ini menunjukkan bahwa aplikasi pupuk hijau Glirisidia 100\% yang diberikan dalam bentuk segar, kering angin dan kering matahari 
Website : http://agritek.unmermadiun.ac.id/index.php/agritek

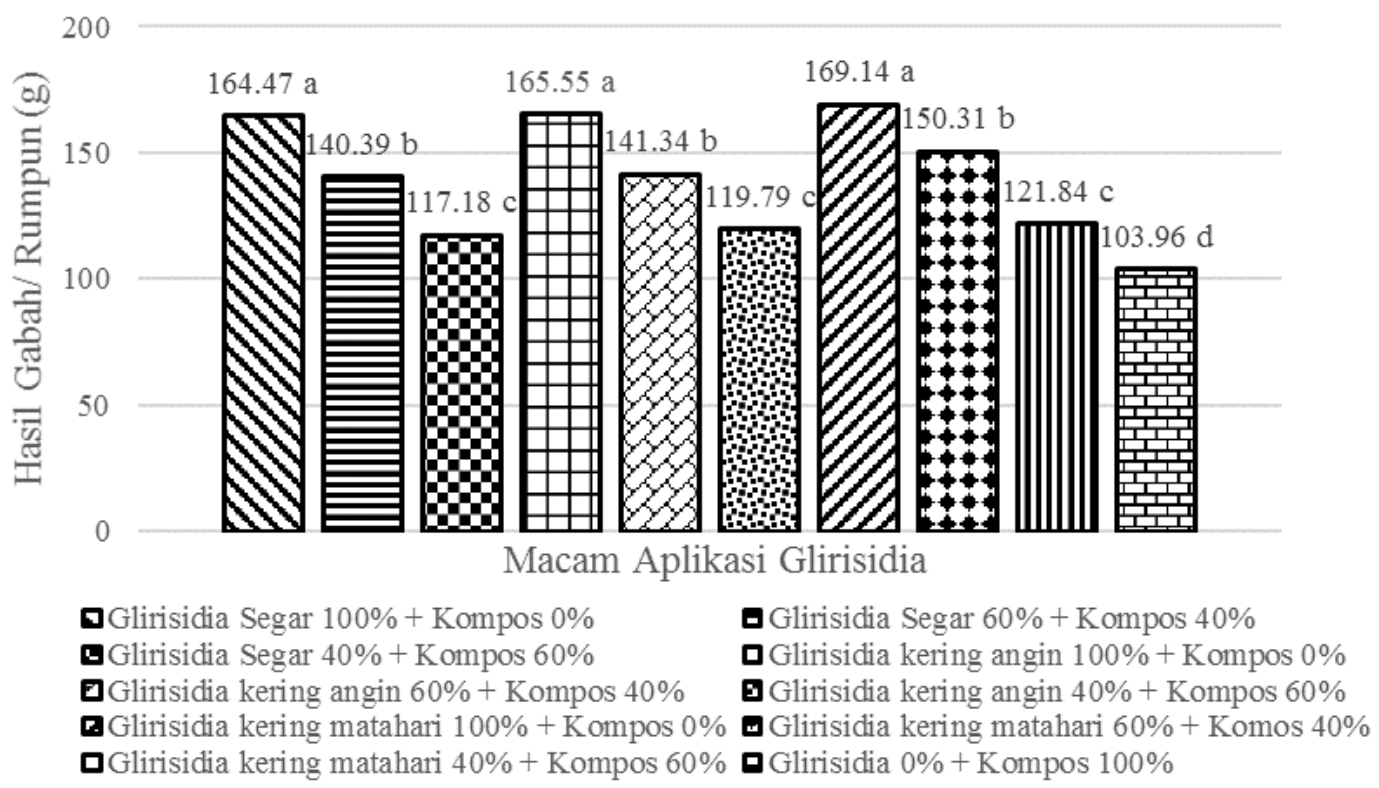

Gambar 1. Hasil Gabah pada Perlakuan Berbagai Macam Aplikasi Pupuk Hijau Glirisidia

mampu menghasilkan komponen hasil yang berupa jumlah malai/rumpun, panjang malai, dan bobot 1000 biji, menyebabkan peningkatan hasil gabah kering giling/rumpun yang lebih tinggi dibandingkan perlakuan lainnya.

Aplikasi N merupakan salah satu amandemen nutrisi yang penting bagi tanah untuk meningkatkan pertumbuhan dan hasil tanaman (Rao, 2006). Pupuk organik yang berasal dari bahan hijau akan terdekomposisi dan melepaskan $\mathrm{N}$ dengan cepat pula. Kondisi ketersediaan $\mathrm{N}$ dalam tanah menentukan jumlah $\mathrm{N}$, yang dapat diserap oleh tanaman (Purwanto, 2014). Nitrogen adalah komponen dari asam amino, protein, asam nukleat, klorofil dan banyak metabolik penting lainnya untuk kelangsungan hidup tanaman. Tanaman yang diberikan pasokan $\mathrm{N}$ cukup akan membentuk daun yang lebih luas dan kandungan klorofil yang lebih tinggi, sehingga tanaman mampu menghasilkan jumlah asimilasi untuk yang cukup menopang pertumbuhan vegetatif (Wijaya, 2008).

Hasil panen gabah/rumpun tertinggi dapat dicapai dengan aplikasi daun Glirisidia $100 \%$ dalam bentuk segar tanpa kompos (164,47 g gabah/rumpun), daun Glirisidia 100\% dalam bentuk segar tanpa kompos kering angin $(165,55 \mathrm{~g}$ gabah/rumpun) dan kering matahari daun Glirisidia 100\% dalam bentuk segar tanpa kompos (169,14 g gabah/rumpun). Peningkatan pertumbuhan tanaman padi menyebabkan peningkatan komponen hasil gabah. Peningkatan jumlah malai/rumpun, panjang malai, dan bobot 1000 biji menyebabkan peningkatan hasil gabah kering giling/rumpun.

\section{KESIMPULAN DAN SARAN}

\section{A. Kesimpulan}

Pengeringan daun Glirisidia tidak menurunkan pertumbuhan dan hasil padi, sehingga daun Glirisidia dapat diaplikasikan dalam bentuk segar, dikering anginkan dalam ruangan atau dikeringkan di bawah sinar matahari. Makin banyak daun Glirisidia yang diaplikasikan makin meningkatkan pertumbuhan dan hasil tanaman padi. Daun
Glirisidia $100 \%$ yang diaplikasikan dalam bentuk segar tanpa kompos, daun Glirisidia 100\% kering angin tanpa kompos atau daun Glirisidia 100\% kering matahari tanpa kompos dapat meningkatkan pertumbuhan tanaman padi dan komponen hasil panen dan hasil panen padi. Hasil panen gabah/rumpun tertinggi dapat dicapai dengan aplikasi daun Glirisidia 100\% segar tanpa kompos $(164,47 \mathrm{~g}$ gabah/rumpun), daun Glirisidia $100 \%$ kering angin $(165,55$ g gabah/rumpun) tanpa kompos atau daun Glirisidia $100 \%$ kering matahari tanpa kompos (169,14 g gabah/rumpun).

\section{B. Saran}

Daun Glirisidia dapat digunakan sebagai pupuk hijau yang diaplikasikan dalam bentuk segar, kering angin atau kering matahari. Jika ketersediaan daun Glirisidia melimpah, maka budidaya padi organik dapat dilakukan dengan aplikasi daun Glirisidia 100\% (25 t/ ha) baik dalam bentuk segar, kering angin atau kering matahari. Perlu pengembangan penelitian lebih lanjut tentang budidaya padi sawah organik dengan aplikasi daun Glirisidia yang dikombinasikan pupuk hayati.

\section{UCAPAN TERIMAKASIH}

Ucapan terimakasih disampaikan kepada Rektor Universitas Merdeka Madiun yang telah memberikan bantuan dana penelitian sehingga penelitian ini dapat terlaksana.

\section{VI.DAFTAR PUSTAKA}

Alagappan, S. and Venkitaswamy, R. 2015. Development of spad values for rice variety $C o(R) 48$ while using various sources of organic manures in comparison with Rdf and Inm at different growth stages of rice for attaining optimum yield. Australian Journal of Basic and Applied Sciences 9(35): 122-125

Hardjowigeno, S, \& M,L, Rayes, 2005, Tanah Sawah, Bayumedia Publishing, Malang, Indonesia,

Hasanuzzaman, M, K,U, Ahamed, N,M, Rahmatullah, N, Akhter, K, Nahar, \& M,L, Rahman, 2010, Plant Growth Characters and Productivity of 
Website : http://agritek.unmermadiun.ac.id/index.php/agritek

Wetland Rice (Oryza sativa L,) as Affected by Application of Different Manures, Emir, Food Agricultural Journal, Vol, 22 (1) : 46-58,

Ikemura, Y, \& K,M, Shukla, 2009, Soil Quality in Organic and Conventional Farms of New Mexico, USA, Journal of Organic Systems, Vol, 4 (1),

Sanati, B. E., J. Daneshiyan, E. Amiri and E. Azarpour. 2011. Study of organic fertilizers displacement in rice sustainable agriculture. International Journal of Academic Research 3 (2): 786-791,

Jahroh, S, 2010, Organic Farming Development in Indonesia: Lessons Learned from Organic Farming in West Java and North Sumatra, ISDA, Montpellier, June 28-30,

Lakitan, B, 2012, Dasar-dasar Fisiologi Tumbuhan, PT, Raja Grafindo Persada, Jakarta, $205 \mathrm{p}$,

Manjappa, K. 2014. Utilization of Eupatorium (Chromoleana odorata), an obnoxious weed as green leaf manure in enhancing rice productivity. IOSR Journal of Agriculture and Veterinary Science 7 (10): 46-48.

Neelima, T,L, \& V,B,B, Murthy, 2008, Growth and Yield Attributes Rice as Influenced by $N$ fertilizer and Differential Incorporation of Sunnhemp Green Manure, Journal of Rice Research, 2 (1) : 45-50,

Ram, M., M. Davari, and S.N. Sharma. 2011. Organic farming of rice (Oryza sativa L.) - wheat (Triticum aestivum L.) cropping system: a review. International journal of Agronomy and Plant Production. Vol., 2 (3), 114-134.

Reddy K,J, 2006, Nutrient Stress, In: K,V,M, Rao, A,S, Raghavendra \& K,J, Reddy, Physiologi and Moleculer Biologi of Sress Tolerance in Plants, Springer, Netherlands, $345 \mathrm{p}$,
Purwanto, B.H., Utami, S.N.H., Indradewa, D. Dan Martono, E. 2014 Pertanian Organik: Solusi Mewujudkan Pertanian Berkelanjutan. Fakultan Pertanian Universitas Gadjah Mada. Yogyakarta.134 halaman.

Simanungkalit, R,D,M, D,A, Suriadikarta, R, Saraswati, D, Setyorini \& W, Hartatik, 2006, Pupuk Organik dan Pupuk Hayati, Balai Besar Litbang Sumberdaya Lahan Pertanian, Badan Pertanian dan Pengembangan Pertanian, Bogor, $312 \mathrm{p}$,

Suriadikarta, D,A, \& R,D,M, Simanungkalit, 2006, Pendahuluan, In Simanungkalit, R,D,M, D, A, Suriadikarta, R, Saraswati, D, Setyorini, dan W, Hartatik, 2006, Pupuk Organik dan Pupuk Hayati, Bala Besar Litbang Sumberdaya Lahan Pertanian, Badan Pertanian dan Pengembangan Pertanian, Bogor, $312 \mathrm{p}$,

Sugito, Y, 2012, Ekologi Tanaman: Pengaruh Faktor Lingkungan terhadap Pertumbuhan Tanaman dan Beberapa Aspeknya, Universitas Brawijaya Press, Malang, $119 \mathrm{p}$,

Tomar, J.M.S., Das, A. and Arunachalam A. 2013. Crop response and soil fertility as influenced by green leaves of indigenous agroforestry tree species in a lowland rice system in northeast India. Agroforestry Systems 87 (1):193-201

Wijaya, K,A, 2008, Nutrisi Tanaman: Sebagai Penentu Kualitas Hasil dan Resistensi Alami Tanaman, Prestasi Pustaka, Jakarta, $121 \mathrm{p}$,

Winarni, M, Yudono, P, Indradewa, D, Sunarminto, B,H, 2016 , Application of Perennial Legume Green Manures to Improve Growth and Yield of Organic Lowland Rice, Journal Degraded and Mining Land Management, 4 (1) : 671-674. 